\title{
Polygenic susceptibility to testicular cancer: implications for personalised health care
}

Updated online 26 May 2016: This article was originally published under a CC BY-NC-SA 4.0 license, but has now been made available under a CC BY 4.0 license. The PDF and HTML versions of the paper have been modified accordingly

Kevin Litchfield ${ }^{1}$, Jonathan S Mitchell ${ }^{1}$, Janet Shipley ${ }^{2,3}$, Robert Huddart ${ }^{4}$, Ewa Rajpert-De Meyts ${ }^{5}$, Niels E Skakkebæk ${ }^{5}$, Richard S Houlston ${ }^{1}$ and Clare Turnbull ${ }^{\star, 1,6}$

${ }^{1}$ Division of Genetics and Epidemiology, The Institute of Cancer Research, London SW3 6JB, UK; ${ }^{2}$ Division of Molecular Pathology, The Institute of Cancer Research, London SW3 6JB, UK; ${ }^{3}$ Division of Cancer Therapeutics, The Institute of Cancer Research, London SW3 6JB, UK; ${ }^{4}$ Academic Radiotherapy Unit, The Institute of Cancer Research, London SW3 6JB, UK; ${ }^{5}$ Department of Growth and Reproduction, Copenhagen University Hospital (Rigshospitalet), Copenhagen, Denmark and ${ }^{6}$ William Harvey Research Institute, Queen Mary University, London EC1M 6BQ, UK

Background: The increasing incidence of testicular germ cell tumour (TGCT) combined with its strong heritable basis suggests that stratified screening for the early detection of TGCT may be clinically useful. We modelled the efficiency of such a personalised screening approach, based on genetic risk profiling in combination with other diagnostic tools.

Methods: We compared the number of cases potentially detectable in the population under a number of screening models. The polygenic risk scoring (PRS) model was assumed to have a log-normal relative risk distribution across the 19 currently known TGCT susceptibility variants. The diagnostic performance of testicular biopsy and non-invasive semen analysis was also assessed, within a simulated combined screening programme.

Results: The area under the curve for the TGCT PRS model was 0.72 with individuals in the top $1 \%$ of the PRS having a nine-fold increased TGCT risk compared with the population median. Results from population-screening simulations only achieved a maximal positive predictive value (PPV) of 60\%, highlighting broader clinical factors that challenge such strategies, not least the rare nature of TGCT. In terms of future improvements, heritability estimates suggest that a significant number of additional genetic risk factors for TGCT remain to be discovered, identification of which would potentially yield improvement of the PPV to 80-90\%.

Conclusions: While personalised screening models may offer enhanced TGCT risk discrimination, presently the case for population-level testing is not compelling. However, future advances, such as more routine generation of whole genome data is likely to alter the landscape. More targeted screening programs may plausibly then offer clinical benefit, particularly given the significant survivorship issues associated with the successful treatment of TGCT.

Testicular germ cell tumour (TGCT) is the most common cancer in men aged 15-45 years (Bray et al, 2006; Ruf et al, 2014). Germ cell tumours account for over $95 \%$ of all testicular cancer, with over 18000 new cases of TGCT diagnosed annually in Europe (Le Cornet et al, 2014). Over the last 30 years there have been significant advances in the treatment of testicular cancer and today, in developed economies, a cure is expected in over $95 \%$ of all patients and in around $80 \%$ of patients presenting with metastatic disease (Siegel et al, 2012; Oldenburg et al, 2013). The success of treating testicular cancer is however accompanied by long-term

*Correspondence: Dr C Turnbull; E-mail: clare.turnbull@icr.ac.uk

Received 19 May 2015; revised 14 July 2015; accepted 19 August 2015; published online 13 October 2015

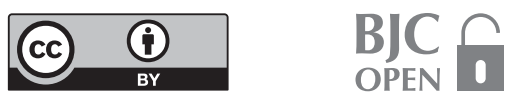


consequences associated with survivorship, such as metabolic syndrome, infertility and secondary cancer (Bujan et al, 2013; de Haas et al, 2013; Rusner et al, 2014). Together with the doubling of TGCT incidence over the last 40 years in Western European countries (Le Cornet et al, 2014) this has been a strong motivator for raising public awareness about TGCT and consideration of potential screening programs. The benefits of any screening programme can however readily be diminished by excessive false-positive findings and high rates of unnecessary intervention. Importantly, any programme in which screening targets only those who have baseline increased risk will reduce such issues while increasing the detection rates for true disease.

Recognised risk factors for TGCT include a family history of testicular cancer, history of cryptorchidism and past history of germ cell tumour (Trabert et al, 2013). Association with various other genitourinary abnormalities has also been variously reported, including microlithiasis, testicular dysgenesis and infertility (Tan et al, 2010; McGlynn and Trabert, 2012; Trabert et al, 2013). While multiple environmental and in utero exposures have been proposed as risk factors, none have been robustly validated (McGlynn and Cook, 2009). Epidemiological studies have consistently demonstrated a 8 - to 10-fold increased risk of TGCT in sibling relationships and a 4- to 6-fold increased risk for parent-son relationships (Hemminki and $\mathrm{Li}, 2004$ ). The strong heritable basis to TGCT risk is supported by twin studies (Swerdlow et al, 1997). Migration studies have shown that part of the familial risk is also likely to be influenced by prenatal exposure to as yet unidentified environmental factors (Myrup et al, 2008). These studies and the failure of linkage analysis to provide evidence for high-risk TGCT predisposition gene(s) is consistent with much of the inherited familial risk being polygenic, enshrined in the co-inheritance of multiple risk variants, some of which are common. Validation for this proposed model of polygenic predisposition to TGCT has come from recent genome-wide association studies (GWAS), which have so far identified 19 risk loci for TGCT (Table 1) (Kanetsky et al, 2009; Rapley et al, 2009; Turnbull et al, 2010; Kanetsky et al, 2011; Turnbull and Rahman, 2011; Chung et al, 2013; Ruark et al, 2013; Schumacher et al, 2013; Litchfield et al, 2014). The risk SNPs identified have some of the highest effect sizes reported for any cancer and collectively the 19 risk SNPs explain 15-20\% of the excess familial risk of TGCT (Litchfield et al, 2015a).

Carcinoma in situ (CIS), also termed germ cell neoplasia in situ (Ulbright et al, 2015), is the non-invasive precursor to TGCT. Molecular and clinical observations are consistent with the first oncogenic transformative step of the progenitor germ cell into CIS occurring during fetal development (Skakkebaek et al, 1987; Rajpert-De Meyts, 2006; Kristensen et al, 2008). Subsequent proliferation of CIS cells occurs during puberty, likely secondary to hormonal influences (Rajpert-De Meyts et al, 2003; Horwich et al, 2006). CIS progresses to invasive TGCT within 7 years for $70 \%$ of cases and practically $100 \%$ will eventually progress (Dieckmann et al, 2011). The universal progression of CIS to invasive TGCT is widely accepted and is supported by equivalent rates of CIS/TGCT and by longitudinal studies. CIS is detectable by double-site testicular biopsy in post-pubertal males and therefore provides a reliable pre-invasive biomarker for TGCT. Recently CIS has been also shown to be detectable by immunocytological techniques based on identification of fetal germ cell markers in cells found in semen samples (Hoei-Hansen et al, 2007; Almstrup et al, 2011).

The genetics of TGCT coupled with CIS acting as a robust biomarker of TGCT offer an attractive schema from which to devise a programme of stratified screening. To explore this possibility we evaluated the predictive discrimination of TGCTrisk SNPs, assessing the application of genetically personalised, multistage population-screening models for TGCT.

Table 1. TGCT predisposition loci used as input for polygenic risk scoring model

\begin{tabular}{|c|c|c|c|c|c|}
\hline SNPa & Gene & Band & Reference(s) & $\begin{array}{l}\text { Risk allele } \\
\text { frequency }\end{array}$ & Per-allele OR \\
\hline $\begin{array}{l}\text { rs995030/ } \\
\text { rs1508595 }\end{array}$ & KITLG & $12 q 21$ & Kanetsky et al, 2009; Rapley et al, 2009 & $0.80 / 0.83$ & $2.55 / 2.69$ \\
\hline rs210138 & BAK1 & $6 p 21$ & Kanetsky et al, 2009; Rapley et al, 2009 & 0.20 & 1.50 \\
\hline rs 4624820 & SPRY4 & $5 q 31$ & Rapley et al, 2009 & 0.54 & 1.37 \\
\hline rs4635969 & TERT/CLPTM1L & $5 p 15$ & Turnbull et al, 2010 & 0.20 & 1.54 \\
\hline rs755383 & DMRT1 & $9 p 24$ & Turnbull et al, 2010 & 0.62 & 1.37 \\
\hline rs2900333 & ATF7IP & $12 p 13$ & Turnbull et al, 2010; Kanetsky et al, 2011 & 0.62 & 1.27 \\
\hline rs8046148 & HEATR3 & $16 q 12.1$ & Ruark et al, 2013 & 0.79 & 1.32 \\
\hline rs2839243 & Non-coding & $21 q 22.3$ & Ruark et al, 2013 & 0.47 & 1.26 \\
\hline rs3805663 & CATSPER3/PITX1 & $5 q 31.1$ & Ruark et al, 2013 & 0.63 & 1.25 \\
\hline rs10510452 & DAZL & $3 p 24.3$ & Ruark et al, 2013 & 0.70 & 1.24 \\
\hline rs2720460 & CENPE & $4 q 24$ & Ruark et al, 2013 & 0.62 & 1.24 \\
\hline rs7010162 & PRDM14 & $8 q 13.3$ & Ruark et al, 2013 & 0.62 & 1.22 \\
\hline rs9905704 & RAD51C/TEX14/PPM1E & $17 q 22$ & Chung et al, 2013 & 0.68 & 1.21 \\
\hline rs3790672 & Non-coding & $1 \mathrm{q} 24.1$ & Ruark et al, 2013; Schumacher et al, 2013 & 0.28 & 1.20 \\
\hline rs2072499 & Non-coding & $1 q 22$ & Chung et al, 2013; Ruark et al, 2013 & 0.35 & 1.19 \\
\hline rs $4888262^{c}$ & RFWD3 & $16 q 22.3$ & Chung et al, 2013 & 0.458 & 1.21 \\
\hline rs12699477 & MAD1L1 & $7 \mathrm{p} 22.3$ & Chung et al, 2013 & 0.38 & 1.16 \\
\hline rs17021463 & HPGDS & $4 q 22.2$ & Chung et al, 2013 & 0.42 & 1.15 \\
\hline rs1510272 & SSR3/TIPARP & $3 q 25$ & Litchfield et al, 2014 & 0.73 & 1.16 \\
\hline \multicolumn{6}{|c|}{ 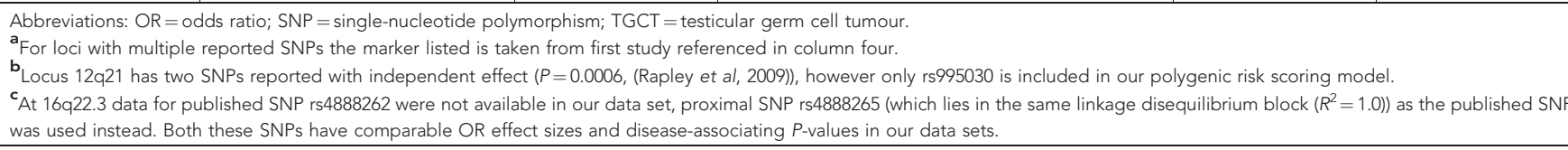 } \\
\hline
\end{tabular}




\section{MATERIALS AND METHODS}

Statistical modelling. The allele frequencies and effect sizes for the 19 TGCT-risk SNPs (Table 1) were obtained from nine published TGCT GWAS (Kanetsky et al, 2009, 2011; Rapley et al, 2009; Turnbull et al, 2010; Turnbull and Rahman, 2011; Chung et al, 2013; Ruark et al, 2013; Schumacher et al, 2013; Litchfield et al, 2014), which draw on the following data sets: (i) two independent GWAS data sets, from the United Kingdom (979 cases/4947 controls) and the United States (349 cases/919 controls); (ii) international consortium meta-analysis that combined data sets from point (i) with five other studies to give a total data set of 4242 cases/9566 controls); and (iii) customised followup array data (3112 cases/14026 controls). To examine the predictive value of the 19 known SNPs we constructed polygenic risk scores (PRS) to capture the collective impact of these variants. The 19 variants were assumed to act independently, based on previous statistical testing that showed no evidence of interaction (Ruark et al, 2013; Litchfield et al, 2014). In brief, the previous tests assessed each pairwise SNP combination using logistic regression, with TGCT as the outcome. The two SNPs were each coded as a categorical variable, while the interaction term $(\mathrm{SNP} 1 \times \mathrm{SNP} 2)$ were included as continuous covariates; for each pairwise combination of SNPs, the joint risk was consistent with the product of the individual risks. We did not test for evidence of higher-order interactions, that is, between three or more SNPs, however it is unlikely these effects would be reliably detectable, if at all present, using current available methodologies (Wei et al, 2014).

The association between TGCT and PRS for all 19 SNPs for an individual is given by:

$$
\beta_{1} x_{1}+\beta_{2} x_{2}+\ldots+\beta_{n} x_{n}
$$

where $\beta_{n}$ is the per-allele log OR and $x_{n}$ the number of risk alleles (either 0,1 or 2 per locus) carried by each individual at each SNP, and $n$ being total number of SNPs. The PRS distribution in the population follows a log-normal distribution $\mathrm{LN}\left(\mu, \sigma^{2}\right)$ with mean $\mu$ and variance $\sigma^{2}$ (i.e. relative risk (RR) is normally distributed on a logarithmic scale). As per Pharoah et al (2002), in cases the distribution of the PRS is given by: $\left(\mu+\sigma^{2}, \sigma^{2}\right)$, that is, with same variance $\sigma^{2}$, but with a mean $\mu$ shifted to the right by $\sigma^{2} . \mu$ and $\sigma^{2}$ are given by:

$$
\sum_{n} p_{n} \beta_{n} \text { and } \sum_{n} p_{n} q_{n} \beta_{n}^{2} \text { respectively, }
$$

where $p_{n}$ is the minor allele frequency of the $n$th SNP and $q_{n}=1-p_{n}$ (Pharoah et al, 2002). For the 19 TGCT-risk loci we calculated $\sigma^{2}=0.74$. The mean PRS from the theoretical distribution is an arbitrary value, calculated as $\exp \left(\mu+\sigma^{2} / 2\right)$, and to give a mean RR in the population of 1.0 we set $\mu=-\sigma^{2} / 2$. This model was then used to calculate the predictions of RR for individuals at or above a given percentile. Receiver operator characteristic (ROC) curves were generated using the same case/population distributions as above, across a set of risk thresholds between $\mu \pm 3 \sigma^{2}$. In addition, ROC curve values were also generated for all TGCT predisposition factors, using familial RR estimates from epidemiological studies. Familial RR is assumed to include both genetic and a proportion of environmental risk factors, for example, shared childhood exposures or in utero exposures. These values were calculated using:

$$
\sigma^{2}=\ln \left(\lambda_{\text {sibling }}^{2}\right)
$$

where $\lambda_{\text {sibling, was estimated using a familial RR of } 8.0 \text { obtained }}$ from Hemminki and Li (2004). Population average lifetime TGCT risk was based on 2014 CRUK lifetime incidence rate of $0.5 \%$ (CRUK, 2014), multiplied by RR to give lifetime risk per percentile of the PRS. Competing mortality risk analysis was not conducted as over three quarters of TGCT cases present at ages 45 years and younger (CRUK, 2014), for whom cumulative mortality risk from all other causes is only $3.6 \%$ (ONS, 2013).

Modelling population screening. To evaluate the utility of the PRS model for population screening for TCGT, we applied genetic risk data in combination with clinical parameters to a theoretical population of 1000000 men. Clinical assumptions and references used in this model are detailed in Table 2 and were taken from four primary sources: Cancer Research UK incidence/mortality statistics, Royal Marsden patient data, a large-scale German study of testicular biopsies by Dieckmann et al and semen assay testing completed at Copenhagen University Hospital. Specifically the models were based on a one-off post-pubertal screening of genotype to identify individuals in the top $1 \%$ of risk (i.e., 10000 men), combined with follow-up testing for the top $1 \%$ to detect the presence of CIS by semen assay/testicular biopsy. The CIS precursor lesion is assumed to be universally present in all individuals that would go on to develop TGCT. Each testing step

\begin{tabular}{|c|c|c|}
\hline Assumption & Value (\%) & Reference \\
\hline Lifetime risk of TGCT & 0.5 & CRUK, 2014 \\
\hline TGCT mortality rate & 2.8 & September 2014 \\
\hline $\begin{array}{l}\text { Frequency of surgical } \\
\text { complications from } \\
\text { testicular biopsy }\end{array}$ & 2.8 & Dieckmann et al, 2011 \\
\hline Semen assay - sensitivity & 67.0 & Almstrup et al, 2011 \\
\hline Semen assay - specificity & 98.0 & Almstrup et al, 2011 \\
\hline $\begin{array}{l}\text { Overall rate of } \\
\text { chemotherapy } \\
\text { administration in } \mathrm{TGCT}\end{array}$ & 65.0 & $\begin{array}{l}\text { Estimate from Royal } \\
\text { Marsden Hospital patient } \\
\text { data }\end{array}$ \\
\hline $\begin{array}{l}\text { Genotyping uptake in } \\
\text { population }\end{array}$ & 100.0 & Theoretical estimate \\
\hline $\begin{array}{l}\text { Sensitivity of testicular } \\
\text { biopsy to detect CIS }\end{array}$ & 97.5 & Dieckmann et al, 2011 \\
\hline $\begin{array}{l}\text { Remaining risk of } \\
\text { progression to invasive } \\
\text { TGCT, following } \mathrm{CIS} \\
\text { detection and preventative } \\
\text { orchidectomy }\end{array}$ & 0.0 & Theoretical assumption \\
\hline
\end{tabular}

Table 2. Clinical assumptions used for population-screening example

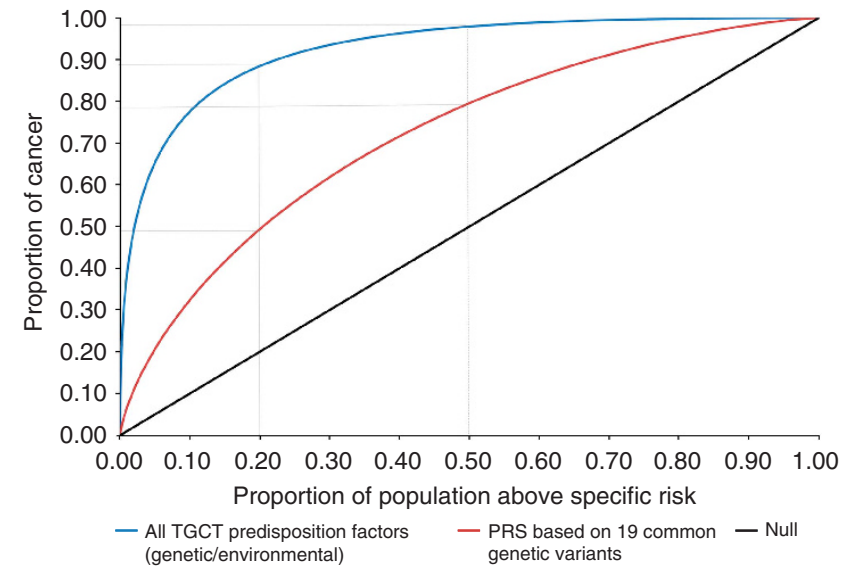

Figure 1. ROC curve for TGCT predisposition factors. 
(genotyping, semen assay and biopsy) is assumed to have the same diagnostic performance for all men.

\section{RESULTS}

Utility of PRS for TGCT risk stratification. Figure 1 shows ROC curves for the PRS model together with the ROC corresponding to all TGCT predisposition factors (genetic and environmental, for

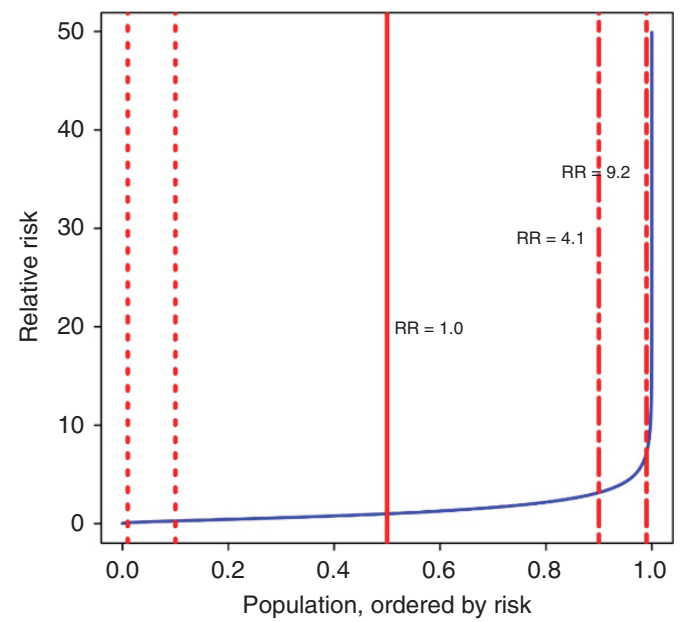

Figure 2. Population distribution of TGCT relative risk scores ordered by genetic risk (risk is relative to population median risk). The blue line plots the distribution of RR across the population; the red lines correspond to 1st, 10th, 50th, 90th and 99th centiles. The RR figures presented in black are the average in the (i) highest 10 and (ii) top 1 centile of genetic risk. reference). The TGCT PRS ROC curve shows that individuals within the top $20 \%$ and $50 \%$ of genetic risk would account for $48 \%$ and $77 \%$ of cases, respectively, equivalent figures for all TGCT predisposition factors being $89 \%$ and $98 \%$, respectively. The area under the curve for the TGCT PRS model is 0.72 . Results from the PRS model shows that men within the top $10 \%$ of genetic risk have a 4.1-fold elevated relative risk of TGCT whilst men within the top $1 \%$ have a 9.2-fold elevated risk of TGCT compared with the population median (Figure 2).

Utility of PRS for TGCT screening at a population level. Figure 3 shows the design and outcome of two- and three-stage populationscreening scenarios, based on one million men, $0.5 \%$ of which would be expected to have CIS and go on to develop invasive TGCT. Under the two-stage screening model, all individuals (one million men) undergo genotype screening across the 19 risk loci, using the PRS model to identify the top $1 \%$ of 'high-risk' individuals (10000 men). These 10000 men would then go on to have a bilateral testicular biopsy for detection of CIS. This strategy would lead to the identification of 449 TGCTs (i.e., $10000 \times 0.5 \%$ (average lifetime risk) $\times 9.2$ (elevation in risk for top $1 \%) \times 97.5 \%$ (biopsy sensitivity) $=449$ ); the balancing 9551 biopsies would return a negative result. The 449 identified CIS cases would then be eligible for preventative surgery, which if assumed to completely eliminate TGCT risk, would result in the prevention of 13 deaths and avoidance of chemotherapy in 292 men. Overall two-stage screening will identify only $9.0 \%$ of TGCT, with a positive predictive value (PPV) for stage 1 genotyping alone of only $4.5 \%$. The negative predictive value is however high, $>99 \%$, reflecting the rarity of TGCT.

We next considered a three-stage screening model (Figure 3), whereby an additional step of semen analysis is conducted after genotype screening but before testicular biopsy. On the basis of

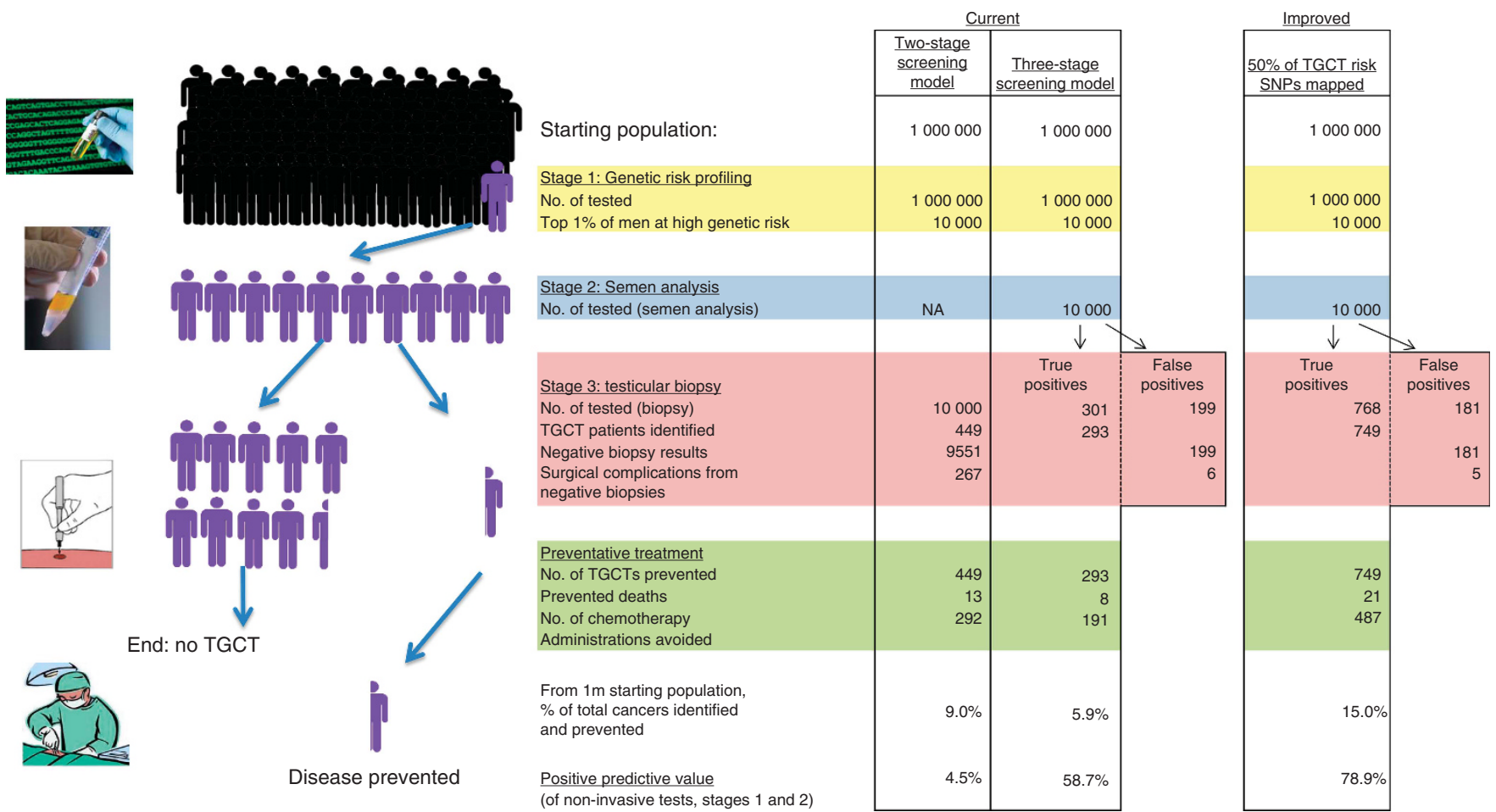

Figure 3. Simulation of two-stage and three-stage population-based screening for TGCT (see Materials and Methods for references underlying individual clinical assumptions applied). The improved model (far right) represents a theoretical best case scenario achievable with current technologies. Specific parameters changed in the improved scenario are: TGCT RR for top $1 \%$ of men increased to 19.2 , equating to an absolute TGCT lifetime risk of $9.6 \%$, an improved semen assay with sensitivity increased from 67 to $80 \%$. 
published sensitivity of $67 \%$ and specificity of $98 \%$ (Almstrup et al, 2011), this extra step reduces the number of testicular biopsies by 20 -fold, whilst still identifying the majority of cases. Under this revised model out of the one million men genotyped, semen analysis is undertaken in 10000 and the resulting number of biopsies would be 500. This would yield identification of 293 TGCTs, the prevention of 8 deaths and administration of chemotherapy avoided in 191 men. The PPV for non-invasive testing (stages $1+2$ ) increases to $58.7 \%$, however the proportion of population cases identified drops to $5.9 \%$.

Utility of PRS for TGCT screening at a population level'improved' model. To assess the impact of future developments on TGCT-screening viability we modelled an 'improved' population-screening scenario, assuming that further risk SNPs can be identified and utilised to improve the PRS performance. In order to estimate how many additional SNPs remain still to be discovered we calculated the total potential contribution of common SNPs to TGCT risk using genome-wide complex trait analysis (Yang et al, 2011), to calculate the heritability of TGCT. This analysis demonstrated that the heritability of TGCT associated with common genetic variants is $37 \%( \pm 5.0 \%)$ (Litchfield et al, 2015b), hence many additional risk SNPs remain to be identified. In the 'improved' model we added the effect of additional as yet unidentified risk SNPs, assuming that with current sample sizes and genotyping technologies half of all common TGCT SNPs could be realistically identified. Incorporating this additional risk discrimination power into the PRS model resulted in an 'improved' RR of 19.2 for men in top $1 \%$ of risk. Using this 'improved' PRS model in combination with an 'improved' semen assay (which we realistically assume has sensitivity improved from 67 to $80 \%$ ), takes the PPV of the combined test from 59 to $79 \%$ (see Figure 3, far right).

\section{DISCUSSION}

The striking effect sizes of TGCT-associated SNPs identified through GWAS, which remain among the highest effect sizes from all GWAS of cancer, have repeatedly raised enquiry as to whether TGCT would be the paradigm through which common genetic variation could first be used clinically to stratify risk (Chanock, 2009). Indeed, the TGCT SNPs demonstrate strength in terms of risk discrimination, for example, the top $1 \%$ of highest risk genotypes had a 9.2-fold elevation in TGCT risk, significantly greater than comparable PRS models of ovarian, breast and prostate cancers with comparative risk figures of 1.9, 3.2 and 4.7, respectively (Bahcall, 2013). This is particularly noteworthy when considering that the PRS model for TGCT is based on the inclusion of only 19 loci, compared with the 71 for breast cancer and 77 for prostate cancer included in their respective models (Eeles et al, 2013; Michailidou et al, 2013). This performance reflects the high effect sizes of the TGCT SNPs. The value of the TGCT PRS must however be considered in a broader clinical context and a number of issues need to be considered alongside the PRS. First, as TGCT is rare with a lifetime male Caucasian absolute risk of 1 in 200, the high relative risks only translate to modest absolute risks. For example, the top $1 \%$ of men with a RR of 9.2 have only a $4.6 \%$ lifetime risk. Second, the high cure rate for TGCT limits the impact of screening and early detection of disease on disease mortality. Third, the invasive and costly nature of testicular biopsy, which with a reported surgical complication rate of around $3 \%$ (Dieckmann et al, 2011), renders it challenging to justify applying this procedure to any large population group. However, advances in non-invasive semen assays to detect CIS, particularly if they can be scaled to high-throughput tests with improved sensitivity, offer real opportunity for transformation of screening for TGCT and avoidance of unnecessary biopsy. Indeed with screening based on a three-stage model the number of required biopsies is reduced significantly by the addition of semen analysis into the protocol. Overall the combination of genetic risk profiling and semen assay likely offers greater clinical utility than genetic risk profiling alone. For example, even using the combination of current genetic PRS (with just 19 SNPs) and current semen assays (with sensitivity of $67 \%$ ) has the potential to achieve a PPV of nearly $60 \%$ when testing an unenriched general population. This is a significant increase from the starting TGCT prevalence of $\sim 0.5 \%$ overall. Further research progress is expected in the fields of both genetic predisposition and semen assays. To explore how these developments might affect TGCT screening we constructed an 'improved' screening model, to represent a theoretical best case scenario achievable with current technologies. This analysis showed men in the top $1 \%$ of risk would have a nearly 20 -fold increase in TGCT risk, and the PPV of a combined test increases to $\sim 80 \%$. As a yardstick of total potential, full mapping of all common TGCT SNPs, as estimated from our genome-wide complex trait analysis, would yield a PPV $>90 \%$, with power to detect and prevent nearly $50 \%$ of TGCTs.

An additional screening approach could be simultaneous testing, with both genetic risk profiling and semen assay testing conducted together in one stage. This approach would have some challenges, for example, given the high specificity (98\%) of the semen assays a positive result on this test would over-ride any result from genetic testing. However, in the scenario of a negative semen assay, due to the low sensitivity of the test (67\%), then genetic testing could be informative in determining whether the semen assay is a true negative or false negative. Overall cost considerations would likely preclude population-wide semen assay testing, and given the rare nature of TGCT, a risk prioritisation stage is likely to be required to identify high-risk men for whom semen testing/biopsy is cost-effective.

A limitation of the current study is the exclusion of non-genetic risk factors, such as cryptorchidism, from the risk scoring model. These factors are likely to offer additional discriminatory power, however explicit delineation of the interaction between genetic and non-genetic factors has yet to be established. Hence, complex modelling trained and tested on clinical data sets fully characterised for genotype and phenotype, would be of significant interest. Indeed if independence of effect can be proved, a model of targeted screening in men with already elevated TGCT risk as evident from their family or medical history may represent a more immediately tractable model for clinical utility. An additional limitation is that health economic analysis has not been considered in our modelling; however, any large-scale programme is currently unlikely to demonstrate savings in health-related expenditure, given the required genotyping of a large initial population. This paradigm is unlikely to shift unless population-level genomic testing becomes routine practice (for example, by way of delivering neonatal screening, although this has ethical implications (Kerruish and Robertson, 2005)), in which context the disease-associating markers could then be routinely queried from broader genomic databases, without incurring additional screening infrastructure or genotyping costs.

Overall the low absolute disease risk and the marked effectiveness of existing treatment for TGCT mean current data do not support a clear compelling case for programs of populationlevel genetic screening for TGCT. However, analysis of future developments suggests a longer-term clinical benefit may exist. Furthermore, there may be more immediate potential benefits from TGCT-screening programs targeting those at elevated a priori risk. The motivation for further developing these risk models for TGCT is clear, in terms of reducing the occurrence of invasive cancer arising in young men, reducing the burden of chemotherapy-related survivorship issues and reducing mortality in the minority with treatment-refractory disease state. 


\section{ACKNOWLEDGEMENTS}

We acknowledge National Health Service funding to the National Institute for Health Research Biomedical Research Centre. This research was supported by the Movember Foundation and the Institute of Cancer Research. KL is supported by a PhD fellowship from Cancer Research UK. We acknowledge the support from the NIHR to the Biomedical Research Centre at The Institute of Cancer Research and Royal Marsden NHS Foundation Trust. We also acknowledge a support from the Danish Cancer Society (R40-Rp6168, to ERDM) and from the Danish National Advanced Technology Foundation (14-2013-4, to NES).

\section{CONFLICT OF INTEREST}

The authors declare no conflict of interest.

\section{REFERENCES}

Almstrup K, Lippert M, Mogensen HO, Nielsen JE, Hansen JD, Daugaard G, Jorgensen N, Foged NT, Skakkebaek NE, Rajpert-De Meyts E (2011) Screening of subfertile men for testicular carcinoma in situ by an automated image analysis-based cytological test of the ejaculate. Int $J$ Androl 34: e21-e30; discussion e30-e31.

Bahcall O (2013) Risk prediction and population screening for breast, ovarian and prostate cancers. Nat Genet 45(4): 343.

Bray F, Ferlay J, Devesa SS, Mcglynn KA, Moller H (2006) Interpreting the international trends in testicular seminoma and nonseminoma incidence. Nat Clin Pract Urol 3: 532-543.

Bujan L, Walschaerts M, Moinard N, Hennebicq S, Saias J, Brugnon F, Auger J, Berthaut I, Szerman E, Daudin M, Rives N (2013) Impact of chemotherapy and radiotherapy for testicular germ cell tumors on spermatogenesis and sperm DNA: a multicenter prospective study from the CECOS network. Fertil Steril 100: 673-680.

Chanock S (2009) High marks for GWAS. Nat Genet 41: 765-766.

Chung CC, Kanetsky PA, Wang Z, Hildebrandt MA, Koster R, Skotheim RI, Kratz CP, Turnbull C, Cortessis VK, Bakken AC, Bishop DT, Cook MB, Erickson RL, Fosså SD, Jacobs KB, Korde LA, Kraggerud SM, Lothe RA, Loud JT, Rahman N, Skinner EC, Thomas DC, Wu X, Yeager M, Schumacher FR, Greene MH, Schwartz SM, McGlynn KA, Chanock SJ, Nathanson KL (2013) Meta-analysis identifies four new loci associated with testicular germ cell tumor. Nat Genet 45: 680-685.

CRUK (2014) Available at http://www.cancerresearchuk.org/cancer-info/ cancerstats/ (accessed on 16 January 2015).

de Haas EC, Altena R, Boezen HM, Zwart N, Smit AJ, Bakker SJ, van Roon AM, Postma A, Wolffenbuttel BH, Hoekstra HJ, van Leeuwen FE, Sleijfer DT, Gietema JA (2013) Early development of the metabolic syndrome after chemotherapy for testicular cancer. Ann Oncol 24: 749-755.

Dieckmann KP, Kulejewski M, Heinemann V, Loy V (2011) Testicular biopsy for early cancer detection-objectives, technique and controversies. Int $J$ Androl 34: e7-e13.

Eeles RA, Olama AA, Benlloch S, Saunders EJ, Leongamornlert DA, Tymrakiewicz M, Ghoussaini M, Luccarini C, Dennis J, Jugurnauth-Little S, Dadaev T, Neal DE, Hamdy FC, Donovan JL, Muir K, Giles GG, Severi G, Wiklund F, Gronberg H, Haiman CA, Schumacher F, Henderson BE, Le Marchand L, Lindstrom S, Kraft P, Hunter DJ, Gapstur S, Chanock SJ, Berndt SI, Albanes D, Andriole G, Schleutker J, Weischer M, Canzian F, Riboli E, Key TJ, Travis RC, Campa D, Ingles SA, John EM, Hayes RB, Pharoah PD, Pashayan N, Khaw KT, Stanford JL, Ostrander EA, Signorello LB, Thibodeau SN, Schaid D, Maier C, Vogel W, Kibel AS, Cybulski C, Lubinski J, Cannon-Albright L, Brenner H, Park JY, Kaneva R, Batra J, Spurdle AB, Clements JA, Teixeira MR, Dicks E, Lee A, Dunning AM, Baynes C, Conroy D, Maranian MJ, Ahmed S, Govindasami K, Guy M, Wilkinson RA, Sawyer EJ, Morgan A, Dearnaley DP, Horwich A, Huddart RA, Khoo VS, Parker CC, Van As NJ, Woodhouse CJ, Thompson A, Dudderidge T, Ogden C, Cooper CS, Lophatananon A, Cox A, Southey MC, Hopper JL, English DR, Aly M, Adolfsson J, Xu J, Zheng SL, Yeager M, Kaaks R, Diver WR, Gaudet MM, Stern MC, Corral R, Joshi AD, Shahabi A,
Wahlfors T, Tammela TL, Auvinen A, Virtamo J, Klarskov P, Nordestgaard BG, Røder MA, Nielsen SF, Bojesen SE, Siddiq A, Fitzgerald LM, Kolb S, Kwon EM, Karyadi DM, Blot WJ, Zheng W, Cai Q, McDonnell SK, Rinckleb AE, Drake B, Colditz G, Wokolorczyk D, Stephenson RA, Teerlink C, Muller H, Rothenbacher D, Sellers TA, Lin HY, Slavov C, Mitev V, Lose F, Srinivasan S, Maia S, Paulo P, Lange E, Cooney KA, Antoniou AC, Vincent D, Bacot F, Tessier DC. COGS-Cancer Research UK GWAS-ELLIPSE (part of GAME-ON) Initiative; Australian Prostate Cancer Bioresource; UK Genetic Prostate Cancer Study Collaborators/ British Association of Urological Surgeons' Section of Oncology; UK ProtecT (Prostate testing for cancer and Treatment) Study Collaborators; PRACTICAL (Prostate Cancer Association Group to Investigate Cancer-Associated Alterations in the Genome) Consortium, Kote-Jarai Z, Easton DF (2013) Identification of 23 new prostate cancer susceptibility loci using the iCOGS custom genotyping array. Nat Genet 45: 385-391; 391e1-391e2.

Hemminki K, Li X (2004) Familial risk in testicular cancer as a clue to a heritable and environmental aetiology. Br J Cancer 90: 1765-1770.

Hoei-Hansen CE, Carlsen E, Jorgensen N, Leffers H, Skakkebaek NE, Rajpert-De Meyts E (2007) Towards a non-invasive method for early detection of testicular neoplasia in semen samples by identification of fetal germ cell-specific markers. Hum Reprod 22: 167-173.

Horwich A, Shipley J, Huddart R (2006) Testicular germ-cell cancer. Lancet 367: 754-765.

Kanetsky PA, Mitra N, Vardhanabhuti S, Li M, Vaughn DJ, Letrero R, Ciosek SL, Doody DR, Smith LM, Weaver J, Albano A, Chen C, Starr JR, Rader DJ, Godwin AK, Reilly MP, Hakonarson H, Schwartz SM, Nathanson KL (2009) Common variation in KITLG and at 5q31.3 predisposes to testicular germ cell cancer. Nat Genet 41: 811-815.

Kanetsky PA, Mitra N, Vardhanabhuti S, Vaughn DJ, Li M, Ciosek SL, Letrero R, D'Andrea K, Vaddi M, Doody DR, Weaver J, Chen C, Starr JR, Håkonarson H, Rader DJ, Godwin AK, Reilly MP, Schwartz SM, Nathanson KL (2011) A second independent locus within DMRT1 is associated with testicular germ cell tumor susceptibility. Hum Mol Genet 20: 3109-3117.

Kerruish NJ, Robertson SP (2005) Newborn screening: new developments, new dilemmas. J Med Ethics 31: 393-398.

Kristensen DM, Sonne SB, Ottesen AM, Perrett RM, Nielsen JE, Almstrup K, Skakkebaek NE, Leffers H, Rajpert-De Meyts E (2008) Origin of pluripotent germ cell tumours: the role of microenvironment during embryonic development. Mol Cell Endocrinol 288: 111-118.

Le Cornet C, Lortet-Tieulent J, Forman D, Béranger R, Flechon A, Fervers B, Schüz J, Bray F (2014) Testicular cancer incidence to rise by $25 \%$ by 2025 in Europe? Model-based predictions in 40 countries using populationbased registry data. Eur J Cancer 50: 831-839.

Litchfield K, Shipley J, Turnbull C (2015a) Common variants identified in genome-wide association studies of testicular germ cell tumour: an update, biological insights and clinical application. Andrology 3: 34-46.

Litchfield K, Thomsen H, Mitchell JS, Sundquist J, Houlston RS, Hemminki K, Turnbull C (2015b) Quantifying the heritability of testicular germ cell tumour using both genomic and population-based approaches. Sci Rep 5: 13889.

Litchfield K, Sultana R, Renwick A, Dudakia D, Seal S, Ramsay E, Powell S, Elliott A, Warren-Perry M, Eeles R, Peto J, Kote-Jarai Z, Muir K, Nsengimana J. UKTCCStratton MR, Easton DF, Bishop DT, Huddart RA, Rahman N, Turnbull C (2014) Multi-stage genome wide association study identifies new susceptibility locus for testicular germ cell tumour on chromosome 3q25. Hum Mol Genet 24(4): 1169-1176.

McGlynn KA, Cook MB (2009) Etiologic factors in testicular germ-cell tumors. Future Oncol 5: 1389-1402.

McGlynn KA, Trabert B (2012) Adolescent and adult risk factors for testicular cancer. Nat Rev Urol 9: 339-349.

Michailidou K, Hall P, Gonzalez-Neira A, Ghoussaini M, Dennis J, Milne RL, Schmidt MK, Chang-Claude J, Bojesen SE, Bolla MK, Wang Q, Dicks E, Lee A, Turnbull C, Rahman N. Breast and Ovarian Cancer Susceptibility CollaborationFletcher O, Peto J, Gibson L, Dos Santos Silva I, Nevanlinna H, Muranen TA, Aittomäki K, Blomqvist C, Czene K, Irwanto A, Liu J, Waisfisz Q, Meijers-Heijboer H, Adank M. Hereditary Breast and Ovarian Cancer Research Group Netherlands (HEBON) van der Luijt RB, Hein R, Dahmen N, Beckman L, Meindl A, Schmutzler RK, Müller-Myhsok B, Lichtner P, Hopper JL, Southey MC, Makalic E, Schmidt DF, Uitterlinden AG, Hofman A, Hunter DJ, Chanock SJ, Vincent D, Bacot F, Tessier DC, Canisius S, Wessels LF, Haiman CA, Shah M, Luben R, Brown J, Luccarini C, 
Schoof N, Humphreys K, Li J, Nordestgaard BG, Nielsen SF, Flyger H, Couch FJ, Wang X, Vachon C, Stevens KN, Lambrechts D, Moisse M, Paridaens R, Christiaens MR, Rudolph A, Nickels S, Flesch-Janys D, Johnson N, Aitken Z, Aaltonen K, Heikkinen T, Broeks A, Veer LJ, van der Schoot CE, Guénel P, Truong T, Laurent-Puig P, Menegaux F, Marme F, Schneeweiss A, Sohn C, Burwinkel B, Zamora MP, Perez JI, Pita G, Alonso MR, Cox A, Brock IW, Cross SS, Reed MW, Sawyer EJ, Tomlinson I, Kerin MJ, Miller N, Henderson BE, Schumacher F, Le Marchand L, Andrulis IL, Knight JA, Glendon G, Mulligan AM. kConFab Investigators; Australian Ovarian Cancer Study Group, Lindblom A, Margolin S, Hooning MJ, Hollestelle A, van den Ouweland AM, Jager A, Bui QM, Stone J, Dite GS, Apicella C, Tsimiklis H, Giles GG, Severi G, Baglietto L, Fasching PA, Haeberle L, Ekici AB, Beckmann MW, Brenner H, Müller H, Arndt V, Stegmaier C, Swerdlow A, Ashworth A, Orr N, Jones M, Figueroa J, Lissowska J, Brinton L, Goldberg MS, Labrèche F, Dumont M, Winqvist R, Pylkäs K, Jukkola-Vuorinen A, Grip M, Brauch H, Hamann U, Brüning T. GENICA (Gene Environment Interaction and Breast Cancer in Germany) Network, Radice P, Peterlongo P, Manoukian S, Bonanni B, Devilee P, Tollenaar RA, Seynaeve C, van Asperen CJ, Jakubowska A, Lubinski J, Jaworska K, Durda K, Mannermaa A, Kataja V, Kosma VM, Hartikainen JM, Bogdanova NV, Antonenkova NN, Dörk T, Kristensen VN, Anton-Culver H, Slager S, Toland AE, Edge S, Fostira F, Kang D, Yoo KY, Noh DY, Matsuo K, Ito H, Iwata $\mathrm{H}$, Sueta A, Wu AH, Tseng CC, Van Den Berg D, Stram DO, Shu XO, Lu W, Gao YT, Cai H, Teo SH, Yip CH, Phuah SY, Cornes BK, Hartman M, Miao H, Lim WY, Sng JH, Muir K, Lophatananon A, Stewart-Brown S, Siriwanarangsan P, Shen CY, Hsiung CN, Wu PE, Ding SL, Sangrajrang S, Gaborieau V, Brennan P, McKay J, Blot WJ, Signorello LB, Cai Q, Zheng W, Deming-Halverson S, Shrubsole M, Long J, Simard J, Garcia-Closas M, Pharoah PD, Chenevix-Trench G, Dunning AM, Benitez J, Easton DF (2013) Large-scale genotyping identifies 41 new loci associated with breast cancer risk. Nat Genet 45: 353-361; 361e1-361e2.

Myrup C, Westergaard T, Schnack T, Oudin A, Ritz C, Wohlfahrt J, Melbye M (2008) Testicular cancer risk in first- and second-generation immigrants to Denmark. J Natl Cancer Inst 100: 41-47.

Oldenburg J, Fossa SD, Nuver J, Heidenreich A, Schmoll HJ, Bokemeyer C, Horwich A, Beyer J, Kataja V, Grp EGW (2013) Testicular seminoma and non-seminoma: ESMO Clinical Practice Guidelines for diagnosis, treatment and follow-up. Ann Oncol 24: 125-132.

ONS (2013) Death Registrations Summary Statistics, England and Wales, 2013.

Pharoah PD, Antoniou A, Bobrow M, Zimmern RL, Easton DF, Ponder BA (2002) Polygenic susceptibility to breast cancer and implications for prevention. Nat Genet 31: 33-36.

Rajpert-De Meyts E (2006) Developmental model for the pathogenesis of testicular carcinoma in situ: genetic and environmental aspects Hum Reprod Update 12: 303-323.

Rajpert-De Meyts E, Bartkova J, Samson M, Hoei-Hansen CE, Frydelund-Larsen L, Bartek J, Skakkebaek NE (2003) The emerging phenotype of the testicular carcinoma in situ germ cell. APMIS 111: 267-278; discussion 278-279.

Rapley EA, Turnbull C, Al Olama AA, Dermitzakis ET, Linger R, Huddart RA, Renwick A, Hughes D, Hines S, Seal S, Morrison J, Nsengimana J, Deloukas P. UK Testicular Cancer CollaborationRahman N, Bishop DT, Easton DF, Stratton MR (2009) A genome-wide association study of testicular germ cell tumor. Nat Genet 41: 807-810.

Ruark E, Seal S, McDonald H, Zhang F, Elliot A, Lau K, Perdeaux E, Rapley E, Eeles R, Peto J, Kote-Jarai Z, Muir K, Nsengimana J, Shipley J.

UK Testicular Cancer Collaboration (UKTCC), Bishop DT, Stratton MR, Easton DF, Huddart RA, Rahman N, Turnbull C (2013) Identification of nine new susceptibility loci for testicular cancer, including variants near DAZL and PRDM14. Nat Genet 45: 686-689.

Ruf CG, Isbarn H, Wagner W, Fisch M, Matthies C, Dieckmann KP (2014) Changes in epidemiologic features of testicular germ cell cancer: age at diagnosis and relative frequency of seminoma are constantly and significantly increasing. Urol Oncol 32: 33 e1-e6.

Rusner C, Streller B, Stegmaier C, Trocchi P, Kuss O, McGlynn KA, Trabert B, Stang A (2014) Risk of second primary cancers after testicular cancer in East and West Germany: a focus on contralateral testicular cancers. Asian J Androl 16: 285-289.

Schumacher FR, Wang Z, Skotheim RI, Koster R, Chung CC, Hildebrandt MA, Kratz CP, Bakken AC, Bishop DT, Cook MB, Erickson RL, Fosså SD, Greene MH, Jacobs KB, Kanetsky PA, Kolonel LN, Loud JT, Korde LA, Le Marchand L, Lewinger JP, Lothe RA, Pike MC, Rahman N, Rubertone MV, Schwartz SM, Siegmund KD, Skinner EC, Turnbull C, Van Den Berg DJ, Wu X, Yeager M, Nathanson KL, Chanock SJ, Cortessis VK, McGlynn KA (2013) Testicular germ cell tumor susceptibility associated with the UCK2 locus on chromosome 1q23. Hum Mol Genet 22: 2748-2753.

Siegel R, DeSantis C, Virgo K, Stein K, Mariotto A, Smith T, Cooper D, Gansler T, Lerro C, Fedewa S, Lin C, Leach C, Cannady RS, Cho H, Scoppa S, Hachey M, Kirch R, Jemal A, Ward E (2012) Cancer treatment and survivorship statistics, 2012. CA Cancer J Clin 62: 220-241.

Skakkebaek NE, Berthelsen JG, Giwercman A, Müller J (1987) Carcinoma-insitu of the testis: possible origin from gonocytes and precursor of all types of germ cell tumours except spermatocytoma. Int J Androl 10: $19-28$.

Swerdlow AJ, De Stavola BL, Swanwick MA, Maconochie NE (1997) Risks of breast and testicular cancers in young adult twins in England and Wales: evidence on prenatal and genetic aetiology. Lancet 350: $1723-1728$

Tan IB, Ang KK, Ching BC, Mohan C, Toh CK, Tan MH (2010) Testicular microlithiasis predicts concurrent testicular germ cell tumors and intratubular germ cell neoplasia of unclassified type in adults: a meta-analysis and systematic review. Cancer 116: 4520-4532.

Trabert B, Zugna D, Richiardi L, McGlynn KA, Akre O (2013) Congenital malformations and testicular germ cell tumors. Int J Cancer 133: 1900-1904.

Turnbull C, Rahman N (2011) Genome-wide association studies provide new insights into the genetic basis of testicular germ-cell tumour. Int J Androl 34: e86-e96; discussion e96-e97.

Turnbull C, Rapley EA, Seal S, Pernet D, Renwick A, Hughes D, Ricketts M, Linger R, Nsengimana J, Deloukas P, Huddart RA, Bishop DT, Easton DF, Stratton MR, Rahman N. UK Testicular Cancer Collaboration (2010) Variants near DMRT1, TERT and ATF7IP are associated with testicular germ cell cancer. Nat Genet 42: 604-607.

Ulbright TM, Amin MB, Balzer B, Berney D, Epstein JI, Guo C, Idrees MT, Looijenga L, Oosterhuis JW, Paner G, Rajpert-De Meyts E, Skakkebæk NE, Tickoo SK, Yilmaz A (2015) Germ cell tumours. In WHO Classification of of Tumours of the Urinary System and Male Genital Organs, Moch H, Humphrey PA, Reuter VE, Ulbright TM (eds) 4th edn, IARC Press: Lyon, France.

Wei WH, Hemani G, Haley CS (2014) Detecting epistasis in human complex traits. Nat Rev Genet 15: 722-733.

Yang J, Lee SH, Goddard ME, Visscher PM (2011) GCTA: a tool for genomewide complex trait analysis. Am J Hum Genet 88: 76-82.

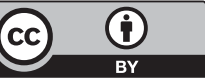

This work is licensed under the Creative Commons Attribution 4.0 International License. To view a copy of this license, visit http://creativecommons.org/licenses/by/4.0/ 